\title{
Religious Tolerance In Indonesia
}

\author{
Sri Widayati, Eka Cahya Maulidiyah \\ Universitas Negeri Surabaya \\ Surabaya, Indonesia \\ Sriwidayati@unesa.ac.id
}

\begin{abstract}
This study aims to describe how religious tolerance in early childhood is formed in Balun Village, Indonesia. This research used qualitative research type with ethnography method. Data were collected through observation, interviews, photo documentation, and written documentation. Data analysis used the Spradley model. The results of the study show that religious tolerance is formed through regional traditional activities involving inter-religious communities. Then, tolerance is also formed through children's daily play activities, and the provision of examples by parents and the environment (sociocultural) which has a very high impact on the cultivation of tolerance for children.
\end{abstract}

Keywords—religious tolerance, early childhood, ethnography

\section{INTRODUCTION}

Indonesia is a maritime country that has various tribes, diverse cultures and religions that live and develop side by side. Various religions in Indonesia have lived and developed for decades in Indonesia. Religions recognized in Indonesia are Islam, Christianity, Catholicism, Hinduism, Buddhism, and Confucianism (Law No. 5 of 1969).

The diversity of religions that exist in Indonesia does not directly make Indonesian people able to live harmoniously side by side, respect one another, respect each other and have strong religious tolerance. In fact, in various regions there have been various conflicts between religious communities which have caused riots and unrest in the society.

The opposite condition is found by researchers in a village called Balun. The Balun village has high inter-religious tolerance. This village is known by the outside community as the Pancasila Village. Inter-religious harmony is evident in this village.

Based on observations made in October 2014, Balun village has three religions, namely: Islam, Christianity and Hinduism. In Balun Village there are three buildings that stand firmly. The building is a mosque as a place of worship for Muslims, the Church as a place of worship for Christians and temples as a place of worship for Hindus. All three buildings are located adjacent to each other.

The results of interviews conducted with village officials and the head of Balun State Primary School 1 supported the results of research observations. In Balun village religious tolerance can be seen through everyday people's behavior. Balun villagers actively hand in hand in carrying out joint activities such as village cleaning or marriage. In a religious marriage, invited guests blend into one. The invited guests consisted of all religions in Balun village. The men in Balun village used skullcaps in wedding and celebration activities even though they were not from Islam.

Tolerance to children is seen in children's play activities that blend without discriminating between religions. Children maintain behavior by not making fun of and ridiculing friends from minority religions.

Based on the explanation above, this study aims to understand how tolerance is formed in children. Several studies that are relevant to research conducted by researchers include: research by Nenden Theresia on the Multicultural Approach in Islamic Schools to Improve Tolerance Attitudes in 2010, R.T. research. [1]

Relevant research has several similarities and differences in implementation. The similarity with the research that will be done is first, the subject of research is the same ie the early childhood. Second, research equally pertains to matters relating to religious tolerance with different research field contexts. From some of the studies above, the general conclusion obtained is that tolerance is very important in fostering relationships in the social diversity of human life. The difference is that there has been no research on religious tolerance for early childhood in religious tolerance communities in Balun Village, Indonesia.

\section{Religious Tolerance}

The essential meaning of tolerance lies in a fair, honest, objective attitude and allows others to do different things in terms of opinion, practice, race, religion, nationality, and ethnicity (ethnicity) with us [2] Tolerance is the ability to respect the nature, beliefs and behaviors of others [3] Tolerance is part of the freedom set by religion in this case Islam, especially freedom of belief and ideology [4] This means that everyone has the right to have in their respective beliefs and Islam is not opposed to the choices they take.

Religious tolerance is the coexistence and coexistence between religious people, including in the norms of the Supreme Behavior of the Almighty, which contributes to the unity of the nation in the principle of the Unity of Indonesia (Hazairin 1995: 169-170). The concept of tolerance in religious life is (1) To appreciate the existence of a religion embraced by a particular society is realized by being able to 
carry out the ritual of worship well, can celebrate religious holidays safely, able to run traditions based on religion well without any interference of parties (2) do not interfere with the life of adherents of other religions, (3) inter-religionists can help each other when necessary, insofar as they are not contrary to their respective religious teachings (Suparta et al, 2009: 179).

Based on some of the expert opinions above, the researchers conclude that religious tolerance is the ability to respect, respect and not interfere with the lives of followers of other religions. In addition tolerance has meaning in a fair, honest, objective attitude, allowing others to do different things regarding their religion. Tolerance is living in harmony and peace as part of religious freedom.

\section{Platform for Religious Tolerance}

The principle of Islam teaches its adherents to exercise tolerance, harmony and peace wherever and whenever. Islam emphasizes the need to establish harmony, tolerance, harmony and peace between fellow Muslims and between religious communities [2] In Al-Qur'an Surat Al-Baqarah verse 256, the provisions of Allah have been stated about the absence of coercion in embracing Islam. According to [5] someone who volunteered and consciously chose one religion, then he was obliged to carry out the teachings of the religion perfectly.

Acknowledging the existence of religion does not mean acknowledging the truth of the religion but so that religious believers can live together side by side peacefully. This is only permitted in worldly matters. In the matter of Islamic faith and worship, Islam expressly forbids to do part and ritual of nonMuslims. This is clearly stated in the Al-Qur'an Surat AlKafirun Verse 6 which reads "for you your religion and for me my religion". Thus Islam views tolerance between religious communities.

The Suweta quoted [3] explains "If we want world unity, religious leaders must have a universal view, world civilization will only grow on the basis of cooperation among all religions." Buddhism also teaches goodness. Kindness as written by Susanto, the Buddha said: "Hatred can never end when rewarded with hatred, but hatred will end in love. This is one eternal law. "(Dhammapada 5) Christianity also shows the same thing, the doctrine of tolerance becomes an inseparable part of Christian doctrine Tolerance is expressed Aloys Budi Purnomo, is nothing but a manifestation of the faith prevailing in every act of the faithful. religion is required to realize his faith in the practical level of every day The manifestation of the faith of a person is not necessarily instantly recognized whether he is a Muslim, Catholic, Protestant, Hindu, Buddhist or whatever.A realistic embodiment of faith in good, harmonious, mutual understanding and mutual acceptance .

Based on the explanation above, it can be concluded that each religion strongly advocates for a good life, harmony and mutual respect among religious followers. This is to create mutual understanding and harmony of religious life.

\section{Social Development}

In social development there are several theories that discuss this, among others: Erikson's theory provides insight into human life in eight stages of human development. In early childhood defined children in the age range $0-8$ years. The stages of development in Erikson's theory are from stage 1 to stage 4 , ie trust versus mistrust, autonomy versus shame and doubt, initiative versus guilt, industry versus inferiority [6]

The next theory is Bronfenbrenner Ecology focuses on the social contexts where children live and those who influence their development. Ecological theory consists of five environmental systems from strong interpersonal relationships to international cultural influences. The five systems are microsystems, ecosystems, ecosystems, macrosystems and ecosystems [7] The subsequent Sociocultural theory put forward by Lev Vygotsky. Vygotsky believes that development is supported by social interaction. This theory emphasizes cooperative dialogue between children and community members so that from there children will learn culture from their community [8].

The various theories mentioned above are synthesized by researchers, namely social development of children consisting of several stages of development. Where each stage has characteristics and development tasks that must be completed. In its socio-emotional development also requires interaction between children and the surrounding environment (social context). Such interaction should guide children to learn effectively to fulfill their learning and development tasks.

\section{Social behavior}

Behavior in conditioning Skinner's behavior, which is the consequence of decisive behavior in changing the likelihood of that behavior [7]. According to the behaviorism flow in Santrock behavior is something that is done both verbally and nonverbally and can be observed directly. The consequences of behavior can be reinforcement, appreciation and punishment. Strengthening behavior can be through positive reinforcement and negative reinforcement. Strengthening can be interpreted to confirm behavior (frequency of response increases).

Bandura believes that the behavior displayed comes from learning to observe the behavior of others, which is then cognitively adopted into self-behavior [7] Social Learning Theory or social cognitive theory emphasizes behavior, environment, and cognition as a key factor in development. Social behavior is used by everyone to start and maintain relationships with others. Social relations have started since birth and according to Morrison it is clear in the interaction between children and other people both parents and teachers [6] The social behavior expressed by Morrison was also supported by the Bronfenbrenner ecological theory which states that children act to influence the system and are influenced by the system [7] These systems are microsystem, mesosystem, ecosystem, macrosystem, chronosystem fund. The next concept is from Lev Vygotsky which emphasizes cooperative dialogue between children and community 
members so that from there children will learn culture from their communities [8]

According to Beaty social action is usually considered as behavior and politeness. In early childhood studies social action refers to how children learn to interact or interact with peers [9] From some of the concepts above, social behavior can be defined as everything done, both verbally and nonverbally and can be observed directly. Social behavior is influenced by cognitive and supported by social interaction with environmental systems and can be made possible by changes in the stimulus and the consequences of these behaviors.

\section{METHOD}

Research that has been conducted using qualitative research with the Spradley ethnographic method. Place and time of study in Balun Village, Lamongan, East Java, Indonesia in 2015. Research procedures using 4 stages, namely the pre-field stage by selecting social situations. Stage of field work by collecting data through observation, documentation and through interviews. Interviews were conducted with village officials, religious leaders, communities, parents and early childhood. Data analysis phase with domain analysis, taxonomic analysis, compound and theme analysis. The final stage is the research report through the validity of the data in the study using extended observations, data triangulation and systematic analysis of research results.

\section{RESULTS AND DISCUSSION}

The results of this ethnographic study include social life in Balun Village as a direct learning resource for early age children to build their knowledge and behavior related to religious tolerance. Behavior tolerance among religious people is maintained so that children learn and practice directly tolerance from an early age. Children tolerate both when playing and while performing religious worship.

The formation of tolerance involves multidisciplinary and interdisciplinary science as illustrated in Figure 1 below:

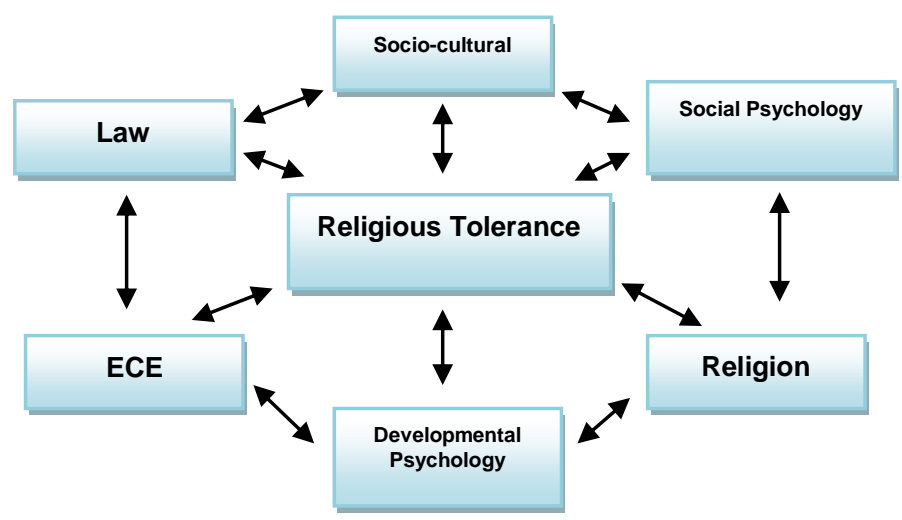

Fig 1. Multidisciplinary and Interdisciplinary Religious tolerance ECE
Examples of children showing religious tolerance are children who never mock about their religion, play without distinguishing friends, do not interfere with friend's worship activities.

The general picture of religious tolerance in early childhood strengthens the concept of religious tolerance. And explains about the practice of the 1945 Constitution article 29 paragraph 2. Besides that the description describes Islam as a majority religion emphasizing the establishment of harmony, tolerance, harmony and peace between fellow Muslims and between religious communities [2]From an early age children are invited and involved to participate in traditional activities and religious activities in the village of Balun. Children are invited to participate in the activities that are there. The family also slowly teaches the meaning of activities carried out simply to children. Children are trained in sensitivity to social situations through everyday life.

This is slowly embedded in the child as knowledge and curiosity to find answers through modeling habituations in parents and the environment around children. In the end the child has knowledge about understanding others in attitudes and behavior in the religious diversity environment in Balun Village.

This is in accordance with Vygotsky about cooperative dialogue between children and community members so that from there children will learn the culture of their community [8] and the results of the study differ from those put forward by Kohlberg about the psychology theory of moral development which mentions that children were originally doing right and wrong judgments is associated with punishment. Children obey for fear of being punished [10]Early childhood in Balun Village performs positive activities such as socializing with other religious friends through play activities.

Balun community tradition contributes positively to the formation of religious tolerance in children. Children can directly see citizens of different religions doing the same activities as pilgrimage to ancestral graves even though with different appearances and praying in their own ways.

Other tolerance is shown through community activities such as slacking and regulating where parents will come using a skullcap even though it is not an Islamic religion. Villagers will be present in every activity of the community even though those who carry out other religions.

This is also clearly seen when there are Hindu religious activities in Pura, Muslims respect by minimizing the call to prayer (voicing the call to prayer by not using speakers). Each religion helps each other. For example, when there are Christian activities in the church, other people maintain parking. When there are things in an activity that intersect with religion, the best solution or behavior is sought without interference with ongoing activities. This is in accordance with Bronfenbrenner's Ecological theory which focuses on the social contexts of the place of residence and people who can influence its development. In the field of early childhood 
education the role of the environment was explained by $\mathrm{Ki}$ Hajar Dewantara. Education is carried out by setting an example, giving encouragement and encouragement to develop or in the famous Javanese language with Ing ngarso sung tulodo, ing madya mangun karso, tut wuri handayani [11] This has been implemented by Balun residents.

\section{CONCLUSION}

The conclusions of this study indicate that (1) religious tolerance is formed through regional traditional activities involving inter-religious communities; 2) Tolerance is also formed through the activities of children's daily play activities. (3) Giving examples by parents and the environment (sociocultural) has an impact on the cultivation of tolerance for children.

\section{References}

[1] R. T. Witenberg, "The moral dimension of children's and adolescents' conceptualisation of tolerance to human diversity," $J$. Moral Educ., vol. 36, no. 4, pp. 433-451, 2007.

[2] F. Ismail, Dinamika kerukunan antarumat beragama: konflik, rekonsiliasi, dan harmoni. PT Remaja Rosdakarya, 2014.

[3] N. Naim and A. Sauqi, Pendidikan multikultural: konsep dan aplikasi. Ar-Ruzz Media, 2008.

[4] S. Hidayat and D. M. H. Basri, Islam, pluralisme \& perdamaian. Fikr, 2008.

[5] M. Q. Shihab, “Membumikan” Al-Quran: fungsi dan peran wahyu dalam kehidupan masyarakat. Mizan Pustaka, 2007.

[6] G. S. Morrison, "Dasar-dasar pendidikan anak usia dini (PAUD)," Jakarta Indeks, 2012.

[7] J. Santrock, "Life-span Development Perkembangan Hidup Jilid 1 Edisi Kelima," Jakarta: Erlangga, 2002.

[8] A. Woolfolk, "Educational psychology, Active Learning Edition, edisi kesepuluh, Trj," Helly Prajitno Soetjipto dan Sri Mulyantini Soetjipto, Yogyakarta Pustaka Pelajar, 2009.

[9] J. J. Beaty, "Observasi perkembangan anak usia dini," Jakarta: Kencana, 2013.

[10] P. Upton, "Psikologi perkembangan," Jakarta: Erlangga, 2012

[11] A. Yus, Model pendidikan anak usia dini. Kencana, 2011. 